\title{
LOWER EOCENE (MIDDLE ILERDIAN) BRACHIOPODS FROM THE CAMPO REGION, CENTRAL PYRENEES, NORTH- EASTERN SPAIN
}

\author{
Maria Aleksandra BITNER \\ Institute of Paleobiology. Polish Academy of Sciences. Twarda 51/55. 00-818 \\ Warszawa. Poland. e-mail: bitner@twarda.pan.pl
}

\begin{abstract}
Bitner, M.A. 2000. Lower Eocene (Middle Ilerdian) brachiopods from the Campo region, Central Pyrenees, north-eastern Spain. [Braquiópodos del Eoceno inferior (Ilerdiense medio) de la región de Campo, Pirineos Centrales, noreste de España.] Revista Española de Paleontología, 15(2), 117-128. ISSN 0213-6937.
\end{abstract}

\begin{abstract}
Three brachiopod species, Terebratulina tenuistriata (Leymerie, 1846), Argyrotheca vidali (Mallada, 1878), and "Terebratula" n. sp., are recognized in the marls and calcareous silts of the Lower Eocene Puebla Formation of the Campo region in the Central Pyrenees, north-eastern Spain. The rich and well preserved material of $T$. tenuistriata and $A$. vidali allows to recognize the range of their morphological variability and to evaluate the status of earlier established species. The investigated assemblage is characterized by the small, pedunculate taxa adapted to life on a soft bottom anchoring directly in a soft substrate or attaching to very small, hard substrates.
\end{abstract}

Keywords: Brachiopoda, taxonomy, Lower Eocene, Ilerdian, Spain.

\section{RESUMEN}

Se han identificado tres especies de braquiópodos: Terebratulina tenuistriata (Leymerie, 1846), Argyrotheca vidali (Mallada, 1878), y "Terebratula" n. sp., en los limos carbonatados y margas del Eoceno inferior de la Formación Puebla en la región de Campo de la Zona Central Pirenaica (noreste de España). La abundancia y buena conservación del material de $T$. tenuistriata y A. vidali ha permitido reconocer el rango de su variabilidad morfológica y evaluar el estatus de las especies descritas previamente. El conjunto estudiado se caracteriza por ser taxones pedunculados pequeños, adaptados a vivir sobre substrato blando, anclándose en dicho substrato, o bien adheridos a partículas duras.

Palabras clave: Brachiopoda, taxonomía, Eoceno inferior, Ilerdiense, España.

\section{INTRODUCTION}

Brachiopods are relatively rare, usually both in species and in number, in the Eocene deposits of Europe, nevertheless they were the subject of study of many researchers (Nyst, 1843; Leymerie, 1846; Davidson, 1852, 1870, 1874; Morgan, 1883; Vincent, 1893, 1923; Oppenheim, 1896, 1901a, b, 1903; Cossmann, 1902; Sacco, 1902; Cossmann and Pissarro, 1903; Doncieux, 1905, 1926; Fabiani, 1913; Dainelli, 1915; Abrard, 1926; Gochev, 1933; Elliott, 1938, 1954, 1955; Meznerics, 1943; Zelinskaya, 1962, 1975; Barczyk, 1973; Makarenko, 1974; Woźny, 1977; Popiel-Barczyk and Barczyk, 1987; Calzada et al., 1988; Calzada, 1994; Calzada and Urquiola, 1994; Popiel-Barczyk, 1996). In many cases, however, material described in the 19th or the beginning of the 20th centuries has never been reinvestigated, and new species were often described on a very limited material, not taking into account intraspecific variation. Moreover, in many cases it is difficult to evaluate the status of those species based on description and illustrations which are not sufficient. Thus, the re-examination and redescription of the Eocene brachiopod material is strongly needed. The material collected in the Campo region and containing three brachiopod species permitted to resolve only some of those taxonomic problems.

It is worth mentioning that also in North America and the Caribbean region the Eocene brachiopods are relatively rare (Toulmin, 1940; Cooper, 1979, 1988; Donovan et al., 1993; Sandy et al., 1995), unlike in the Southern Hemisphere and Japan where they are an important element of fauna (Hatai, 1940; Lee, 1986; Bitner, 1996). 


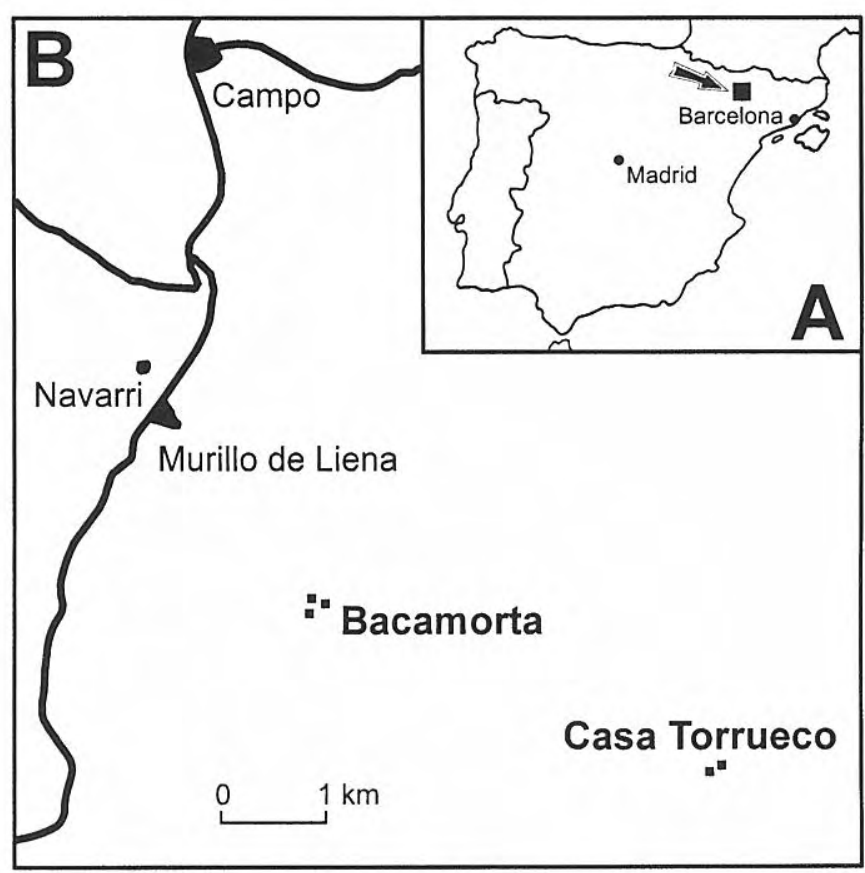

Figure 1. A. Location map; the study area in B is arrowed. B. Sketch location of studied sites.

\section{LOCATION, MATERIAL AND METHODS}

The brachiopod-bearing deposits in the Campo region, Central Pyrenees belong geologically to the Tremp-Graus basin, and are a part of the more than $700 \mathrm{~m}$ thick sequence of the Ilerdian and Cuisian parastratotype (Tosquella, 1988; Molina et al., 1992; Serra-Kiel et al., 1993). The Ilerdian is represented by thick and relatively continuous marine deposits. The Early and lowermost Middle Ilerdian consists of limestones alternating with marls in the upper part, while the rest of the Middle and Late Ilerdian is composed of more than $550 \mathrm{~m}$ thick silty marls (Molina et al., 1992). Based on the rich microfossil record the age of the Ilerdian is defined as Upper Paleocene-Lower Eocene (Molina, 1996).

The investigated brachiopods come from the extremely fossiliferous silts and marls of the Middle Ilerdian Puebla Formation, equivalent to the La Pobla level of Tosquella (1988). In addition to brachiopods, the diverse marine fauna includes foraminifers, ostracods, sponges, bryozoans, bivalves, echinoids, crinoids, serpulids, and crabs.

The brachiopods described in this paper come from two localities, Bacamorta and Casa Torrueco, in the Campo region, Central Pyrenees, north-eastern Spain (Fig. 1). They were collected directly in the field from the weathering surface enriched in fossils; seven bulk samples (five from Bacamorta and two from Casa Torrueco) weighting about $4-5 \mathrm{~kg}$ were also taken and then washed at the laboratory (mesh $0.5 \mathrm{~mm}$ ). The brachiopods are in 95 percent articulated, however, they are sometimes slightly damaged or crushed. Many of them, especially smaller specimens, were covered by epitaxial calcite cement and/or by sediment, thus being very difficult to clean. The total number of collected specimens is 1606 (1325 from Bacamorta and 281 from Casa Torrueco). There are also many fragments of various size.

The investigated material is housed in the Institute of Paleobiology of the Polish Academy of Sciences (Warsaw) under the collection number ZPAL Bp.XLIII.

\section{SYSTEMATIC DESCRIPTION}

ORDER TEREBRATULIDA Waagen, 1883

SUBORDER TEREBRATULIDINA Waagen, 1883

Superfamily CANCELLOTHYROIDEA Thomson, 1926

Family Cancellothyrididae Thomson, 1926 Genus Terebratulina d'Orbigny, 1847

Type species: Anomia retusa Linnaeus, 1758.

Terebratulina tenuistriata (Leymerie, 1846) Figs. 2, 3, 4 A-F, 5 A-G

1829 Terebratula striatula J. de C. Sowerby, 69-70 (partim), pl. 536, fig. 5 (non figs. 3-4).

1846 Terebratula tenuistriata Leymerie, 363, pl. 15, fig. 11.

1846 Terebratula Defrancii Brongniart; Leymerie, 367, pl. 15, fig. 12.

1846 Terebratula tenuistriata Leym.; d'Archiac, 214, pl. 7, fig. 14.

1847 Terebratula tenuistriata Leym.; d'Archiac, 412, pl. 13, fig. 12 .

1852 Terebratulina striatula, Sow., Sp.; Davidson, 14-15, pl. 1 , figs. $16,16 \mathrm{a}, 16 \mathrm{~b}$.

1870 Terebratulina striatula (Sow. ?); Davidson, 400-401, pl. 19, figs. 21, 21a.

1874 Terebratulina Putoni Baudon; Davidson, 155-156, pl. 7, fig. 15.

1874 Terebratulina Woodi Nyst; Davidson, 157, pl. 8, fig. 10.

1893 Terebratulina Woodi, Nyst; Vincent, 45-47, pl. 3, figs. 8-11.

1893 Terebratulina Putoni, Baudon; Vincent, 48.

1893 Terebratulina Delheidi, nov. sp.; Vincent, 48-50, pl. 3, figs. 5-7.

1901a Terebratulina striatula Sowerby; Oppenheim, 258, pl. 15 , fig. 15 .

1905 Terebratulina tenuistriata Leymerie; Doncieux, 90-92, pl. 4, figs. 7-10.

1913 Terebratulina striatula Sowerby; Fabiani, 32-33, pl. 4, figs. 3-5.

1915 Terebratulina striatula Sowerby; Dainelli, 408.

1926 Terebratulina tenuistriata Leymerie; Doncieux, 12-15, pl. 1, figs. 41-43; pl. 2, figs. 1-19.

1926 Terebratulina tenuistriata Leymerie; Abrard, 270.

1933 Terebratulina tenuistriata Leym.; Gochev, 29.

1938 Terebratulina wardenensis sp. nov.; Elliott, 128-131, fig. 23: 1-20.

1943 Terebratulina striatula Sowerby; Meznerics, 34-35, pl. 2 , fig. 7.

1954 Terebratulina wardenensis Elliott; Elliott, 723. 

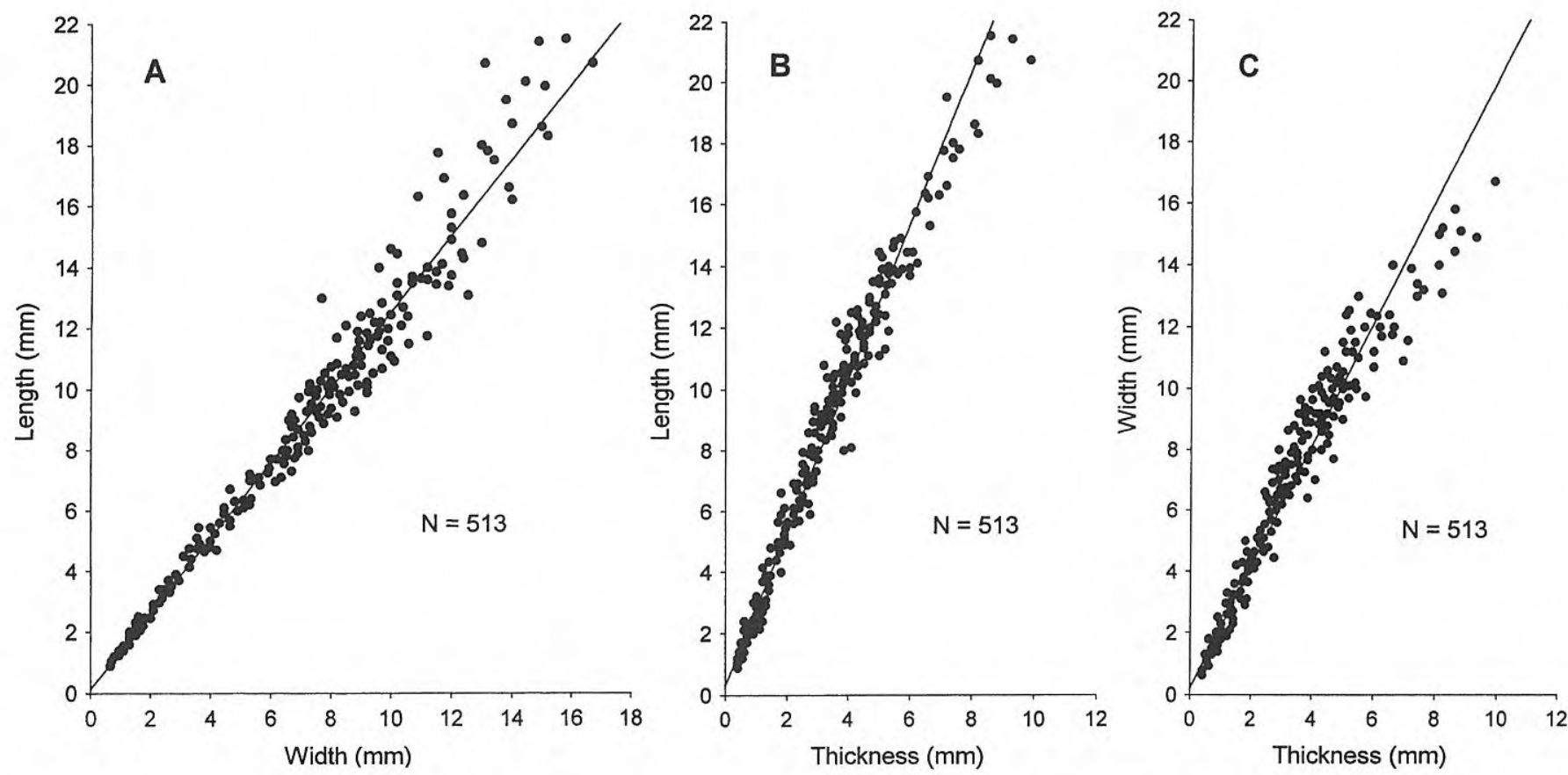

Figure 2. Intraspecific variability of Terebratulina tenuistriata (Leymerie, 1846) from the Campo region. Scatter diagrams plotting length/width (A), length/thickness (B), width/thickness (C). N - number of specimens.

1973 Terebratulina delheidi Vincent; Barczyk, 492-496, text-figs. 1-4, pl. 1, figs. 1-9.

1987 Terebratulina rudis Koenen; Popiel-Barczyk and Barczyk, 94-96, text-figs. 2-3, pl. 1, figs. 1-3.

1987 Terebratulina aff. rudis Koenen; Popiel-Barczyk and Barczyk, 96, pl. 1, figs. 4-5.

1987 Terebratulina sp.; Popiel-Barczyk and Barczyk, 96-97, pl. 1 , fig. 6.

1992 Terebratulina striatula Sowerby; Altichieri, 217.

Dimensions (in mm; see also Fig. 2):

$\begin{array}{lccc} & \text { L } & \text { W } & \text { T } \\ \text { ZPAL Bp.XLIII/1 } & 21.5 & 15.8 & 8.6 \\ \text { ZPAL Bp.XLIII/2 } & 20.7 & 13.1 & 8.2 \\ \text { ZPAL Bp.XLIII/3 } & 21.4 & 14.9 & 9.3 \\ \text { ZPAL Bp.XLIII/5 } & 19.1 & 15.0 & 8.8 \\ \text { ZPAL Bp.XLIII/10 } & 14.9 & 11.2 & 5.1 \\ \text { ZPAL Bp.XLIII/11 } & 16.6 & 13.9 & 7.2 \\ \text { ZPAL Bp.XLIII/15 } & 10.7 & 9.8 & 5.7\end{array}$

Material: 728 complete specimens, three ventral valves and 21 dorsal valves from Bacamorta, and 80 complete specimens, four ventral valves and five dorsal valves from Casa Torrueco. Some specimens are slightly damaged.

\section{Diagnosis}

Medium-sized Terebratulina ornamented by numerous fine ribs; anterior commissure incipiently to broadly uniplicate; ring-like brachidium with long crura.

\section{Remarks}

The species Terebratulina tenuistriata (Leymerie) is the commonest one in the investigated material (more than 800 specimens). It was already noted from the
Paleogene deposits of southern France and northern Spain, being known from the Thanetian (Upper Paleocene) to the Bartonian (Middle Eocene).

The specimens under study are consistent with those described and illustrated by Leymerie (1846) and Doncieux $(1905,1926)$ from the Montagne Noire, however they differ from them in being slightly smaller. A great variability in shell outline and convexity, already reported by Doncieux $(1905,1926)$, is also visible in the studied material. The outline, independently of the size, can vary from ovally elongate to nearly circular (see Fig. $4 \mathrm{~B}-\mathrm{E})$. The shell is always biconvex but in various degree. The anterior commissure rectimarginate in young specimens becomes slightly uniplicate in adults. The shell surface is covered with numerous, very fine ribs, and the changes in ornamentation can be observed during ontogenesis. The individuals of 1-2 $\mathrm{mm}$ long have only 10-12 ribs (Fig. 5 A-C) which increase rapidly in number with a brachiopod age. In younger specimens, usually till $8 \mathrm{~mm}$ long, ribs are clearly granular, becoming completely smooth and very fine in larger specimens. The foramen is large, oval to circular, mesothyrid to permesothyrid, restricted anteriorly by two small, triangular, disjunct deltidial plates. The cardinalia with prominent inner socket ridges and cardinal process developed as a transverse subcircular area, and brachidium forming a ring-like loop (Fig. 3) represent typical characteristics of the genus Terebratulina.

The Eocene specimens of Terebratulina were also described under the name $T$. striatula (Sowerby), even recently this name was used by Altichieri (1992). However, the specific name striatula is not valid for the Tertiary species. Sowerby (1829) found the specimens from the London Clay (Eocene) very similar to the Upper 


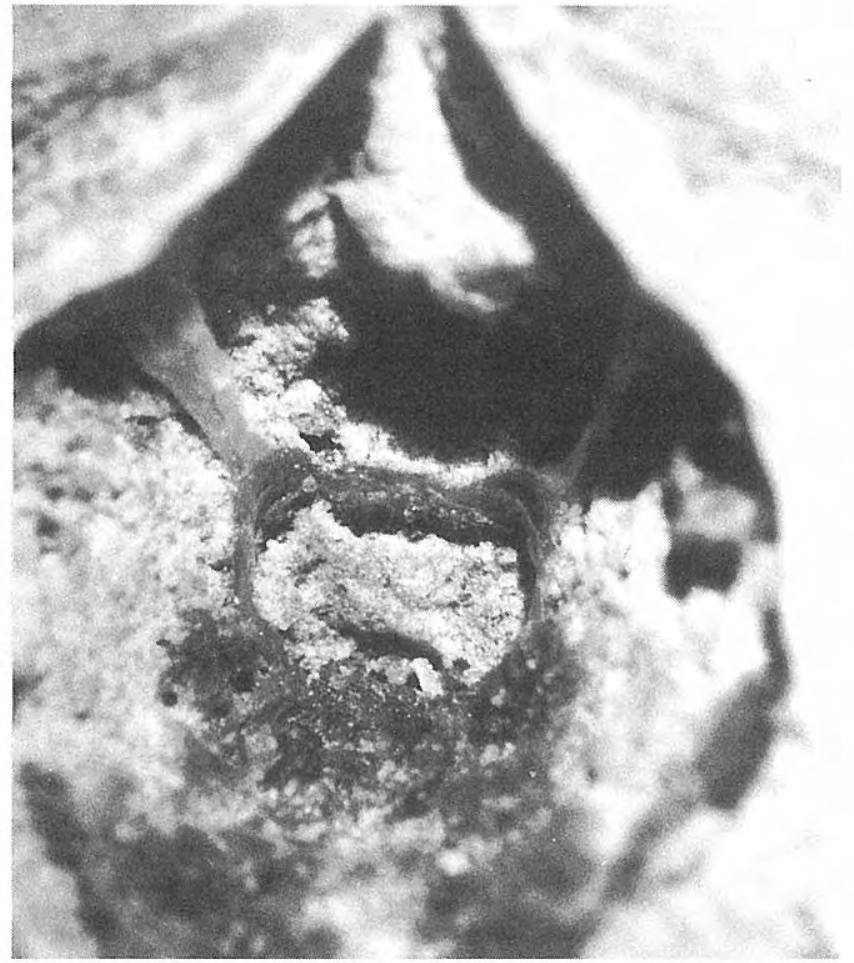

Figure 3. Terebratulina tenuistriata (Leymerie, 1846), ringlike brachidium seen from dorsal side, ZPAL Bp.XLIII/6, Bacamorta, sample 1, x 20.

Cretaceous species Terebratula striatula Mantell, 1822, and used this name of the Cretaceous species for his Eocene specimens. Davidson (1852), however, found both forms were distinct and restricted the name striatula only to the Tertiary specimens, wrongly believing that the forms from the Chalk were conspecific with the Swedish Cretaceous species $T$. striata (Wahlenberg, 1821), and thus the specific name striatula, as a younger one, can be used to the Tertiary forms. As shown by Elliott (1938) and later by Owen (1988), in his revision of the Cretaceous brachiopods, the name Terebratulina striatula (Mantell) should be correctly applied only to the Upper Chalk forms. Since the name for Tertiary forms was occupied, Elliott (1938) proposed a new specific name wardenensis to replace the name striatula. Examining the large material from Spain, as well as from France and England (collections in The Natural History Museum in London), and descriptions and illustrations of the Eocene specimens attributed to $T$. striatula (sensu Sowerby, 1829) and $T$. tenuistriata I found no difference between those two species. Also other authors (e.g. d'Archiac, 1846; Davidson, 1870; Oppenheim, 1901a; Fabiani,
1913) pointed out a great similarity of $T$. striatula (sensu Sowerby, 1829) and $T$. tenuistriata. Slight differences in ornamentation of both species fit well within the range of the intraspecific variability. Thus, $T$. tenuistriata and $T$. striatula (sensu Sowerby, 1829) should be considered as synonyms, thereby $T$. tenuistriata and $T$. wardenensis are also synonyms, and the name tenuistriata has priority over the name wardenensis.

The specimens from the Eocene of Belgium (Davidson, 1874; Vincent, 1893) described as Terebratulina Putoni Baudon, T. Woodi Nyst, and T. Delheidi Vincent have all the features consistent with those of $T$. tenuistriata and are included by me into the synonymy of the latter. Both Davidson (1874) and Vincent (1893) stressed a great similarity of those species to the English species $T$. striatula Sowerby, the species considered in this paper as synonymous with $T$. tenuistriata.

Terebratulina delheidi Vincent from the Eocene of the Tatra Mts. (Barczyk, 1973) are smaller than the specimens of T. tenuistriata from Spain, however, outline and style of ribbing point to their being conspecific. It is interesting to mention that Barczyk (1973) included $T$. striatula into the synonymy of $T$. delheidi.

Also Sacco (1902) described several forms from the Eocene of Italy as the varieties of Terebratulina caputserpentis (Linnaeus, 1767), however, many of them may be situated within the intraspecific variability of $T$. tenuistriata.

Zelinskaya (1975), with material from the Eocene of the Ukraine, recognized and created many species of Terebratulina, based sometimes only on one specimen. The particular Terebratulina species created by her differ often between each other only slightly in size, outline, and differently defined sinus on a ventral valve. Some of those species seem to be very similar to the studied material. Nevertheless in many cases it is difficult to estimate the validity of the species because of unsufficient description and poor quality of illustrations.

Further investigations of Eocene representatives of Terebratulina are badly needed to clarify taxonomic status of those numerous species.

\section{Occurrence}

It is known from the Upper Paleocene and Eocene of Europe (from Spain to Bulgaria).

\section{SUBORDER TEREBRATELLIDINA Muir-Wood, 1955 Superfamily MEGATHYRIDOIDEA Dall, 1870}

Figure 4. A-F. Terebratulina tenuistriata (Leymerie, 1846), Bacamorta; A. Complete specimen, ZPAL Bp.XLIII/5, sample 1, x 2, a, dorsal view; b, lateral view; B-E. Dorsal views of complete specimens, ZPAL Bp.XLIII/15-18, sample 2, x 3; F. Complete specimen, ZPAL Bp.XLIII/10, sample 4, x 3, a, ventral view; b, dorsal view; c, lateral view; d anterior view. G-N. Argyrotheca vidali (Mallada, 1878); G. Complete specimen, ZPAL Bp.XLIII/34, sample 2, x 4, a, ventral view; b, dorsal view; c, lateral view; H-I. Complete specimens, ZPAL Bp.XLIII/43-44, Bacamorta, sample 3, x 4, a, ventral views; b, dorsal views; c, lateral views; J-M. Dorsal views of complete specimens; J-L. ZPAL Bp.XLIII/31-33, Bacamorta, sample 2, x 4; M. ZPAL Bp.XLIII/55, Casa Torrueco, sample 2, SEM x 8; N. Ventral view of complete specimen, ZPAL Bp.XLIII/56, Casa Torrueco, sample 2, SEM x 10. 


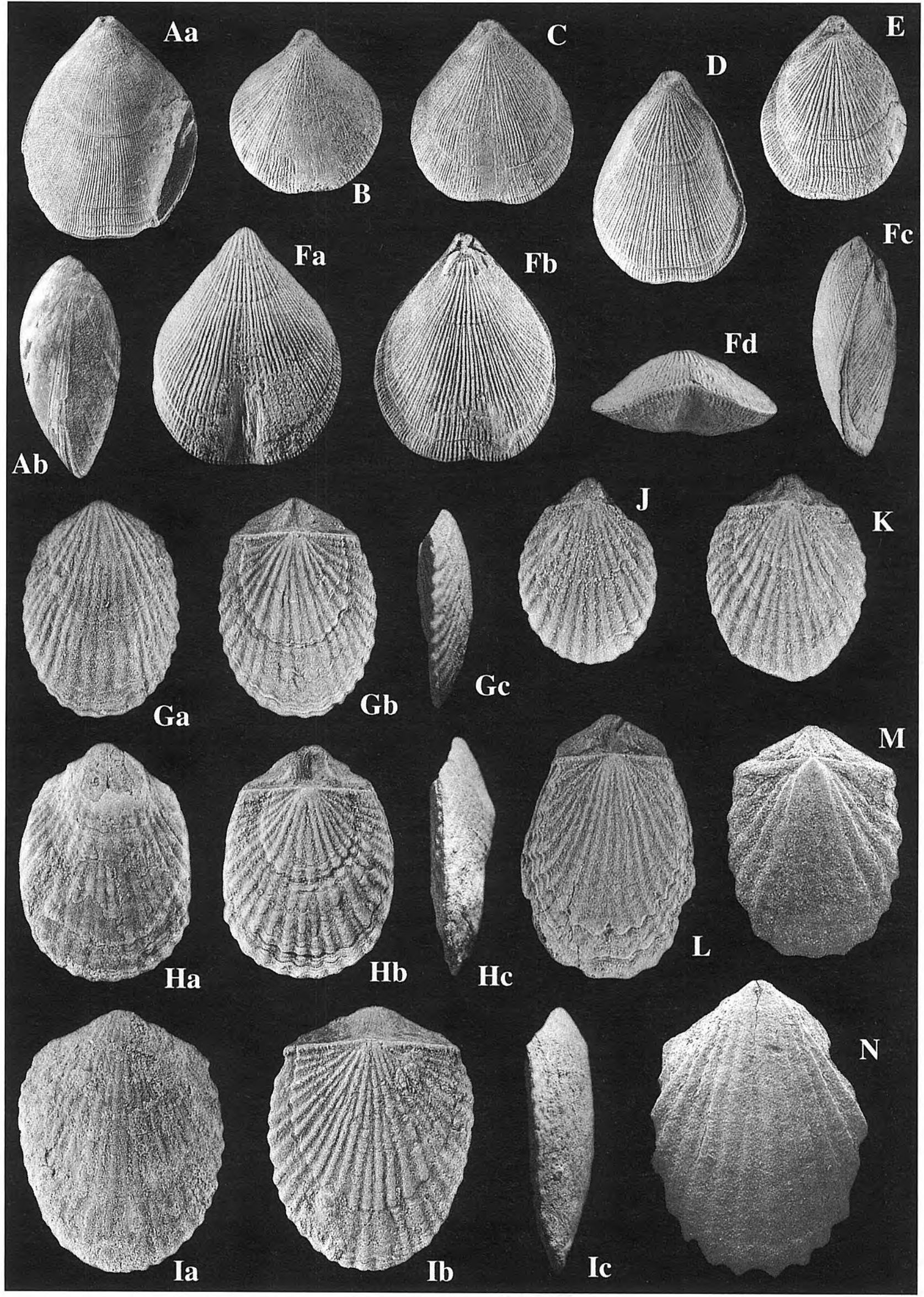




\section{Remarks}

Megathyrid brachiopods were earlier assigned to the superfamily Terebratelloidea, however, detail studies of the loop ontogeny of the megathyrid brachiopods and terebratelloids show significant differences, thus indicating the necessity to separate megathyrids into a different superfamily (MacKinnon and Smirnova, 1995). Also immunological data confirm that they are phylogenetically different (Endo et al., 1994).

\section{Family Megathyrididae Dall, 1870 Genus Argyrotheca Dall, 1900}

Type species: Terebratula cuneata Risso, 1826.

\section{Argyrotheca vidali (Mallada, 1878)}

Figs. 4 G-N, 5 H-P, 6

1870 Terebratulina ? Michelottina (Dav.); Davidson, 401, pl. 19 , figs. 22, 22a, b, c.

1878 Terebratula vidali Mallada, 398, pl. 12, figs. 1-5.

1901a Terebratulina Michelottina Davidson; Oppenheim, 257, pl. 15, fig. 16.

1913 Terebratulina michelottina Davidson; Fabiani, 36-37, pl. 4, figs. $15,15 \mathrm{a}$.

1926 Cistella lemoinei nov. sp.; Abrard, 271, fig.

1954 Cistellarcula wrigleyi, sp. nov.; Elliott, 726-727, pl. 15 , figs. 8-12.

1992 Terebratulina michelottina Davidson; Altichieri, 217.

1994 Argyrotheca lemoinei (Abrard); Calzada and Urquiola, 21-22, figs. 3, 5:2a-c.

1994 Argyrotheca vidali (Mallada); Calzada and Urquiola, 22-24, figs. 4-5:3a-c.

Dimensions (in mm; see also Fig. 6):

\begin{tabular}{lrll} 
& \multicolumn{1}{c}{ L } & W & T \\
ZPAL Bp.XLIII/33 & 10.5 & 7.0 & 2.7 \\
ZPAL Bp.XLIII/34 & 8.7 & 6.4 & 2.3 \\
ZPAL Bp.XLIII/35 & 11.8 & 6.7 & 3.3 \\
ZPAL Bp.XLIII/39 & 12.0 & 8.6 & 3.4 \\
ZPAL Bp.XLIII/42 & 12.3 & 8.9 & 3.6 \\
ZPAL Bp.XLIII/43 & 10.4 & 7.5 & 2.9 \\
ZPAL Bp.XLIII/44 & 11.6 & 9.0 & 3.0
\end{tabular}

Material: 425 complete specimens, 10 ventral valves and 11 dorsal valves from Bacamorta, and 166 complete specimens, nine ventral valves and five dorsal valves from Casa Torrueco.

\section{Emended diagnosis}

Argyrotheca variable in outline from subrectangular to elongate oval, always longer than wide, and ornamented by coarse ribs varying from 18 to 30 in number.

\section{Remarks}

The Eocene Argyrotheca species from Spain were recently revised and described by Calzada and Urquiola (1994) on the basis of the material from the Vic Basin, Catalonia. They recognized three species: Argyrotheca batalleri (Abrard, 1926), A. lemoinei (Abrard, 1926) and A. vidali (Mallada, 1878). Although they pointed out to a great similarity of the two last species, they preferred to leave them as different taxa. Those two species were separated, however, from each other only on the basis of the characters such as shell outline, small differences in size, and slightly differently defined ribs which usually can vary considerably in one species. Examining the rich material (more than 600 specimens) from the Campo region and the collection from the Museu Geològic del Seminari described by Calzada and Urquiola (1994) I reached the conclusion that all those features fit very well within the intraspecific variability range. I have found that all the intermediate forms can be observed, thus, $A$. lemoine $i$ and $A$. vidali are considered by me as conspecific, with the specific name vidali having the priority.

This micromorphic species is generally elongate and varies from subrectangular with a straight hinge line, nearly so long as the maximum width, to oval with a shorter hinge margin and the greatest width at the midlength, and drop-like in outline with very short hinge line and the greatest width in the anterior half (see Fig. 4 G-L). The shell is strongly punctate and covered with numerous rounded ribs. Individuals of $1 \mathrm{~mm}$ or less long, however, are smooth having only shallow sulcus on both valves (Fig. 5 I-J). In slightly larger specimens 4-6 rounded, very low ribs, with shallow grooves, appear on the anterior margin (Fig. $5 \mathrm{H}$ ). The ribs increase by intercalation and 18-30 ribs can be observed in adults. The shell is unequally biconvex, with the ventral valve much deeper, the dorsal one is nearly flat. The beak with sharp beak ridges and well developed area is truncated by a large, triangular, hypothyrid pedicle opening restricted by two small deltidial plates; the pedicle collar well developed and supported by a low median septum. The dorsal median septum extends

Figure 5. A-G Terebratulina tenuistriata (Leymerie, 1846), young specimens; A-B. Dorsal views of complete specimens, ZPAL Bp.XLIII/19-20, Bacamorta, sample 5, SEM x 40; C. Ventral view of complete specimen, ZPAL Bp.XLIII/21, Bacamorta, sample 5, SEM x 30; D-F. Dorsal views of complete specimens, Bacamorta, SEM x 15, D, F - ZPAL Bp.XLIII/22-23, sample 5, E. - ZPAL Bp.XLIII/30, sample 7; G. Ventral view of complete specimen, ZPAL Bp.XLIII/24, Bacamorta, sample 5, SEM x 15. H-P Argyrotheca vidali (Mallada, 1878), young specimens; H. Ventral view of complete specimen, ZPAL Bp.XLIII/51, Bacamorta, sample 7, SEM x 40; I-J. Dorsal views of complete specimens, Bacamorta, SEM x 40, I - ZPAL Bp.XLIII/50, sample 6, J - ZPAL Bp.XLIII/45, sample 5; KN. Dorsal views of complete specimens, ZPAL Bp.XLIII/46-49, Bacamorta, sample 5; K - SEM x 25; L-M - SEM x 20; N - SEM x 15; O-P. Dorsal views of complete specimens, ZPAL Bp.XLIII/59-60, Casa Torrueco, sample 2, SEM x 15 . 


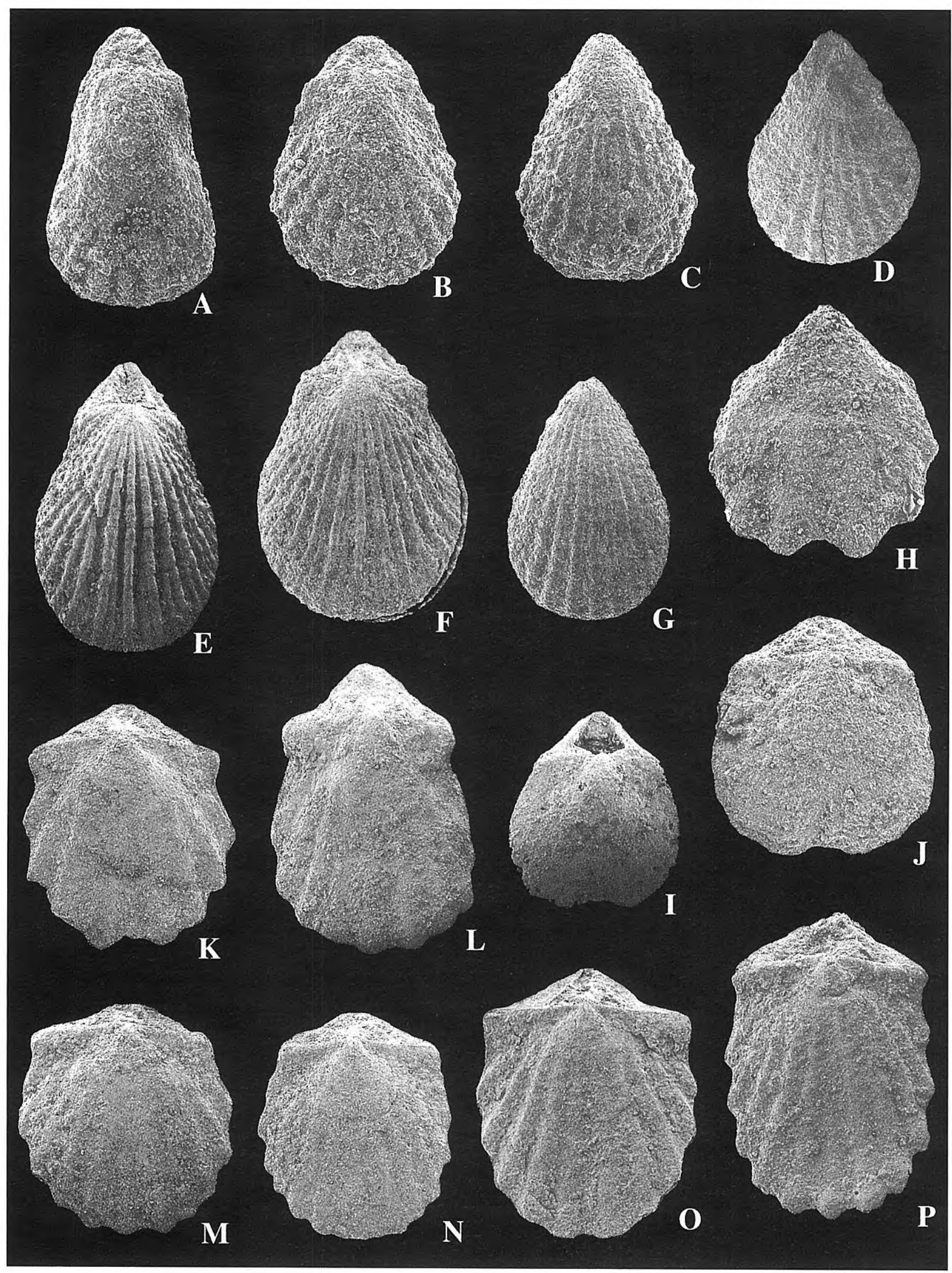



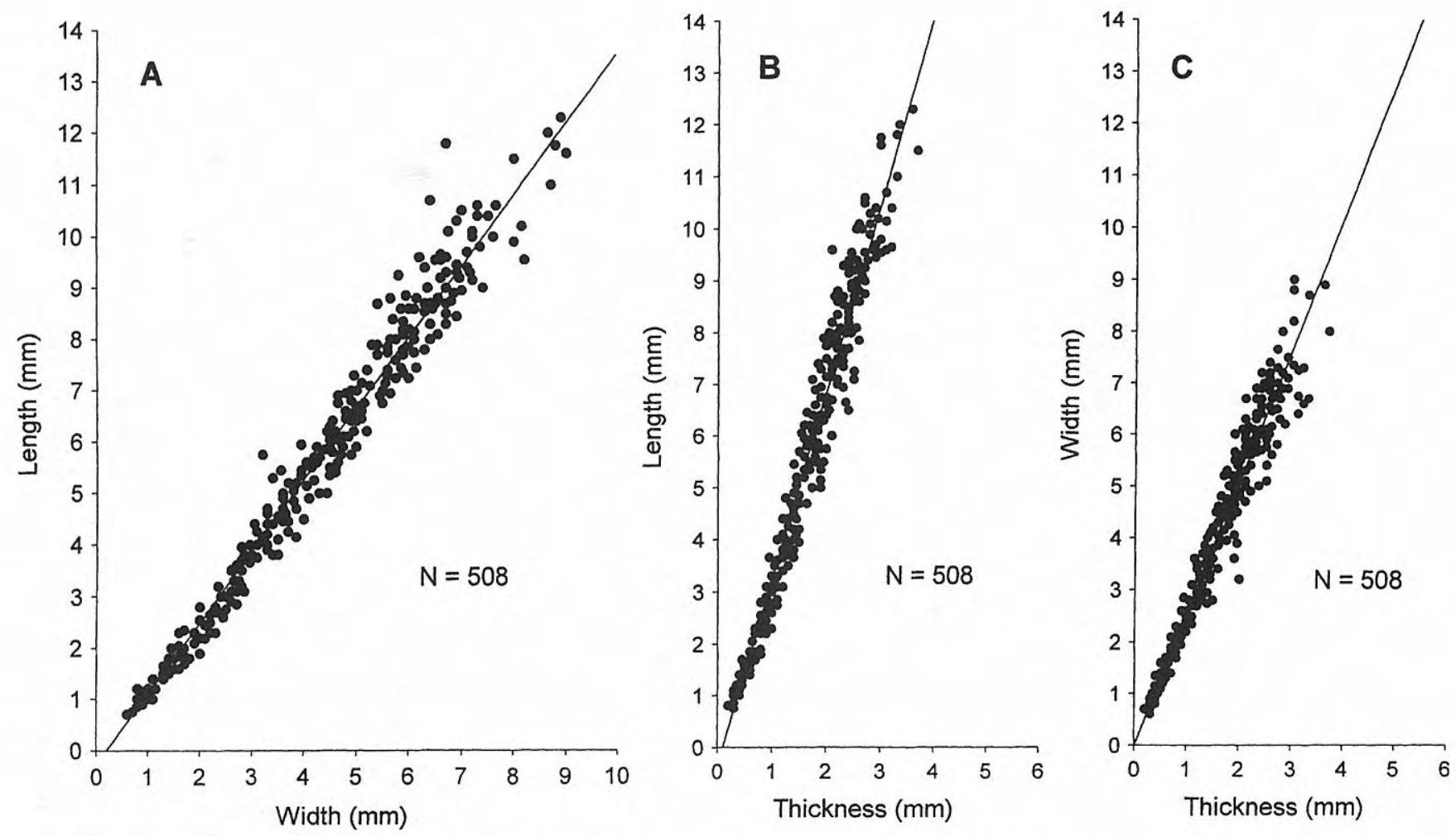

Figure 6. Intraspecific variability of Argyrotheca vidali (Mallada, 1878) from the Campo region. Scatter diagrams plotting length/width (A), length/thickness (B), width/thickness (C). $\mathrm{N}$ - number of specimens.

for two-thirds the length of the valve. It is highest posteriorly and bears 8-10 serrations facing ventrally. The brachial loop is not preserved in the studied material.

The species A. vidali can be easily distinguished from another Spanish Eocene species occurring in the Vic Basin, A. batalleri (Abrard) by its shell outline and ornamentation. A. batalleri is subsquare in outline and covered with sharper ribs with grooves between them wider than ribs themselves.

The specimens described by Davidson (1870) under the name Terebratulina? Michelottina exhibit typical characteristics of the genus Argyrotheca, such as straight hinge line, nearly equal to the shell width, flat area with large and triangular hypothyrid pedicle opening restricted by narrow deltidial plates. Moreover, in size, outline and ornamentation of rounded ribs $T$. michelottina agrees very well with $A$. vidali.

Elliott (1954) created a new genus and species, Cistellarcula wrigleyi, for the specimens from the Eocene strata of the French Pyrenees. Elliott's material, although represented only by few specimens rather poorly preserved, is entirely consistent with $A$. vidali. I agree with the opinion of Calzada and Urquiola (1994) that the characters used by Elliott (1954) to create a new genus are not sufficient to distinguish those two genera, i.e. Argyrotheca and Cistellarcula.

\section{Occurrence}

Lower and Middle Eocene of southern Europe (France, Spain and Italy).
Family uncertain

"Terebratula" n. sp.

Figs. 7-8

Dimensions (in mm; see also Fig. 8):

$\begin{array}{llll} & \mathrm{L} & \mathrm{W} & \mathrm{T} \\ \text { ZPAL Bp.XLIII/103 } & 1.4 & 1.1 & \\ \text { ZPAL Bp.XLIII/105 } & 2.0 & 1.8 & 0.6 \\ \text { ZPAL Bp.XLIII/106 } & 2.6 & 2.2 & 0.8 \\ \text { ZPAL Bp.XLIII/120 } & 2.4 & 2.2 & 0.8 \\ \text { ZPAL Bp.XLIII/122 } & 2.1 & 1.8 & 0.6 \\ \text { ZPAL Bp.XLIII/125 } & 3.1 & 2.8 & 1.1 \\ \text { ZPAL Bp.XLIII/126 } & 2.5 & 2.3 & 0.8\end{array}$

Material: 127 complete specimens from Bacamorta, and 12 complete specimens from Casa Torrueco. Few specimens are slightly crushed.

\section{Description}

The shell is very small (max. length $3.1 \mathrm{~mm}$ ), thin and translucent, weakly biconvex, with the dorsal valve slightly more convex. The shell outline varies from ovally elongate in young specimens to subcircular in adults. The shell surface is completely smooth, no growth lines are visible. In two specimens there are fragments of surface with punctae visible. The ventral beak is straight, pointed. The pedicle opening is large, triangular, of hypothyrid type, restricted by two narrow, disjunct deltidial plates. The hinge line is short and slightly curved. The anterior commissure is rectimarginate. Through the translucent shell no significant internal structure is visible. 


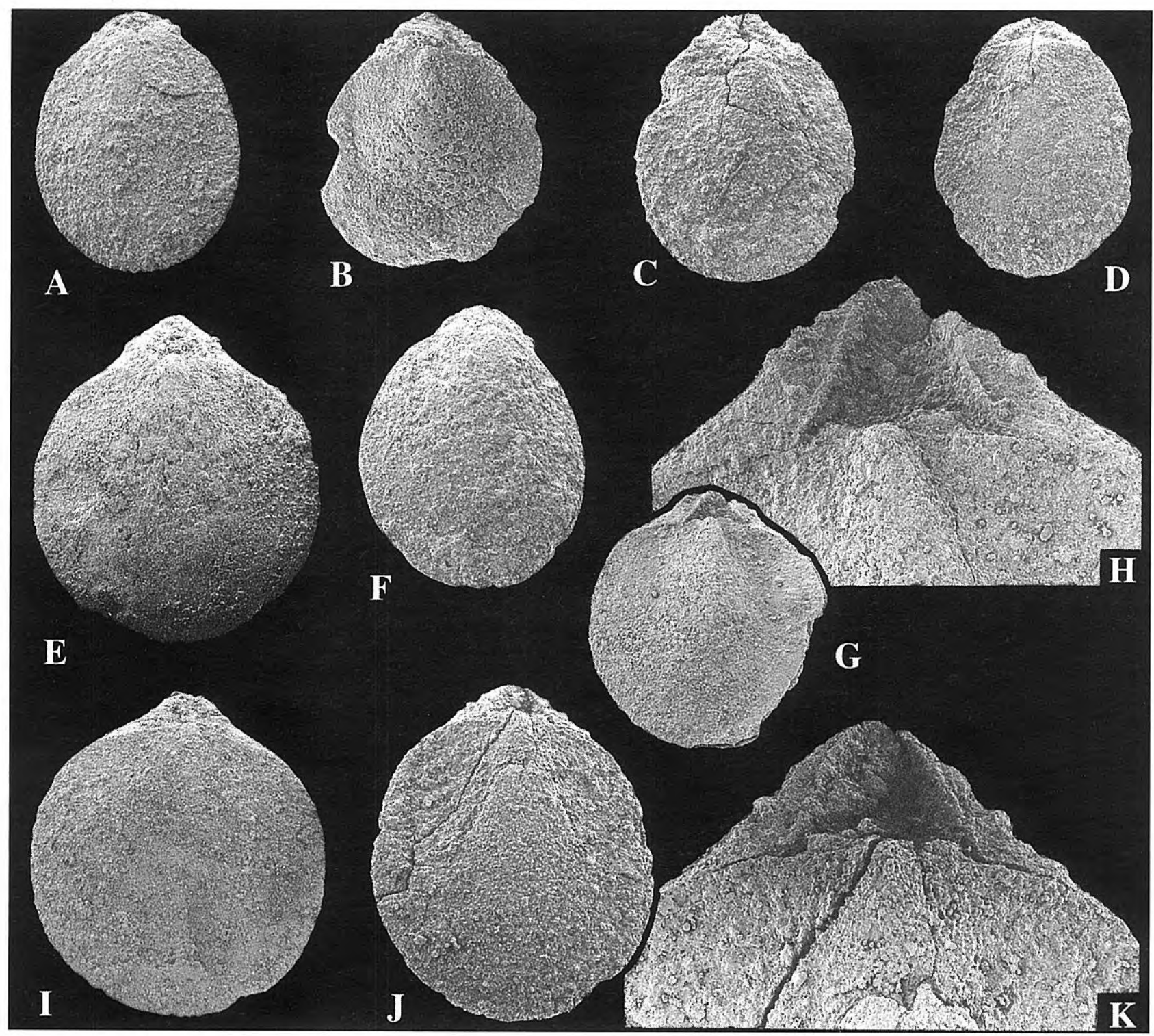

Figure 7. "Terebratula" n. sp., Bacamorta; A-C. Dorsal views of complete specimens, ZPAL Bp.XLIII/101-103, sample 7; A SEM x 25, B-C - SEM x 30; D-F. Dorsal views of complete specimens, ZPAL Bp.XLIII/121-123, sample 9; D SEM x 40, E-F - SEM x 25; G-H. Complete specimen, ZPAL Bp.XLIII/104, sample 7; G - dorsal view, SEM x 20; $\mathrm{H}$ - enlarged of $\mathrm{G}$ to show details of the posterior part of the shell, SEM x 65; I. Dorsal view of complete specimen, ZPAL Bp.XLIII/120, sample 9, SEM x 20; J-K. Complete specimen, ZPAL Bp.XLIII/105, sample 7; J - dorsal view, SEM x 25; K - enlarged of J to show details of the posterior part of the shell, SEM x 65 .

\section{Remarks}

The state of preservation, unknown internal structures and the absence of any characteristic features make the determination of the systematic position of this micromorphic species very difficult. In some cases overgrowth by cement crystals may obliterate the shell microstructure, not allowing even to differentiate between terebratulids and rhynchonellids. Those smooth, small terebratulids, for instance, display a great similarity to the rhynchonellid genus Cryptopora Jeffreys, as already noted by Pajaud and Tambareau (1970). The punctation, however, preserved in two specimens excludes such possibility. Also the absence of the dorsal median septum, which should be clearly visible through the translucent shell, makes the discussed specimens different from Cryptopora. The same difficulties were also pointed by Pajaud in Pajaud and Tambareau (1970) and in Pajaud and Plaziat (1972) who studied similar material from the Upper Paleocene. He decided to attribute informally his new species to "Terebratula". In effect, I follow Pajaud's approach attributing also the studied specimens to "Terebratula", however not creating formally a new species.

The specimens from the Campo region are very close to the Upper Paleocene species "Terebratula" lapichensis Pajaud (in Pajaud and Tambareau, 1970: 318-320). They differ from this species, however, in being slightly smaller and having rectimarginate anterior commissure. They also display an opposite than the specimens from the Petites Pyrénées tendency in the shell shape - 

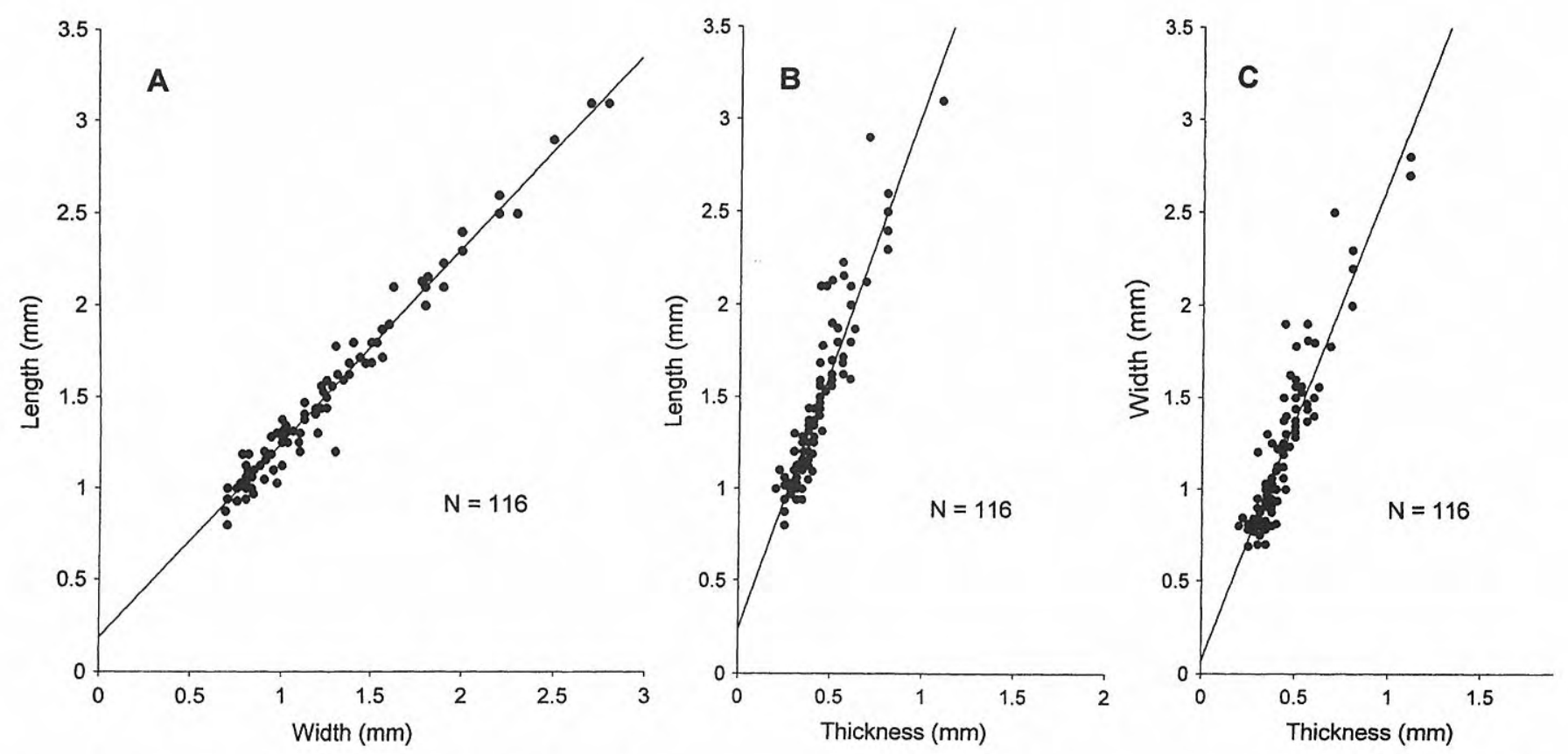

Figure 8. Intraspecific variability of "Terebratula" n. sp. from the Campo region. Scatter diagrams plotting length/width (A), length/thickness (B), width/thickness (C). N - number of specimens.

immature specimens are elongate becoming transverse when adults (compare Fig. 8A and fig. 4B in Pajaud and Tambareau, 1970).

The specimens under study show also some similarities to the species "T." liusa from the Thanetian of the Basque region described by Pajaud in Pajaud and Plaziat (1972). They differ from them, however, in much larger size, in more transverse shell outline and in having rectimarginate anterior commissure.

\section{Occurrence}

Lower Eocene of north-eastern Spain.

\section{ECOLOGICAL CONDITIONS OF THE BRACHIOPOD FAUNA}

The investigated brachiopod assemblage from the Campo region, although rich in specimens (more than 1600 ), is of low diversity; only three brachiopod genera are represented. The brachiopod fauna is generally well preserved; 95 percent of the specimens are articulated, indicating lack or a short distance of post-mortem transport. Epizoans on the brachiopod shells are very rare. They include bryozoans, serpulids, oysters, and foraminifers. Also predatory activity is very low. Gastropod borings are observed on five specimens only. Few specimens show signs of nonlethal predatory attacks of some unknown predator.

The particular species display slightly different frequency patterns. Terebratulina tenuistriata (Leymerie) and Argyrotheca vidali (Mallada) are present in all collecting samples, while "Terebratula" n. sp. was found in five samples, in two others being absent.

The composition of fauna and type of sediment may suggest similar interpretation of the ecological conditions as for the white chalk assemblage with dominance of small, pedunculate taxa inhabiting soft bottom (Surlyk, 1972). The species from the Campo region belong to two ecological categories among those distinguished by Surlyk (1972). T. tenuistriata, the largest species in the investigated material, belong to a group of medium-sized brachiopods that lived attached directly to the fine sediment by a rooted pedicle, well known mode of life of Recent Terebratulina species (Curry, 1981). The micromorphic pedunculate species, A. vidali and "Terebratula" n. sp. belong to another group of minute forms that were able to use very small, hard substrates, such as small bryozoans, mollusc shell fragments or serpulids recognized in the sediment.

\section{ACKNOWLEDGEMENTS}

I would like to express my gratitude to Drs Josep SerraKiel and Josep Tosquella (Barcelona University) for introducing me into the field. Dr. J. Tosquella also helped me in collecting brachiopods. Part of the work was done during my stay at the University of Barcelona thanks to invitation by Professor Salvador Reguant and Dr. Pere Busquets (Barcelona University). Special thanks are due to Professor Jordi Martinell (Barcelona) for accepting me in his lab. Drs Sebastián Calzada (Barcelona) and Barbara Studencka (Warszawa) kindly assisted by arranging facilities to study the material stored in the Museu Geològic del Seminari and Muzeum Ziemi, respectively. Through the kindness of Ms. Sarah Long (London) I had the opportunity to study the brachiopod collections housed in The Natural History Museum, London. I am particularly thankful to Dr. Ellis F. Owen (London) for reading the manuscript and 
improving the English language. I am also indebted to Dr. Josep Serra-Kiel who read the manuscipt and suggested some modifications. Ms. Sarah Long and Dr. Neda Motchurova-Dekova (Sofia) helped me with some papers difficult to find. Ms. Laia Alegret Badiola (Zaragoza) and Dr. J. Serra-Kiel helped me with the Spanish abstract. This paper benefited from the thoughtful reviews of Drs Fernando Álvarez (Oviedo) and Eustoquio Molina (Zaragoza). The photographs were taken by Ms.Grażyna Dziewińska (Warszawa) to whom I am very grateful. The SEM micrographs were taken in the SEM laboratory of the Institute of Paleobiology (Warszawa) using Philips XL-20 scanning microscope.

\section{REFERENCES}

Abrard, R. 1926. Nota sobre quelques braquiopodes lutecians de Catalunya. Ciencia, 1, 270-271.

Altichieri, L. 1992. Aggiornamento sulla fauna dei Brachiopodi delle Venezie. Memorie di Scienze Geologiche, 46, 211-227.

Archiac, M. A. d' 1846. Description des fossiles recueillis par M. Thorent, dans les couches à nummulines des environs de Bayonne. IV. Mémoires de la Société Géologique de France, 2e série, 2, 189-217.

Archiac, M. A. d' 1847. Description des fossiles du groupe nummulitique recueillis par M. S.-P. Pratt et M. J. Delbos aux environs de Bayonne et de Dax. Mémoires de la Société Géologique de France, 2 série, 3, 397-456.

Barczyk, W. 1973. Brachiopods Terebratulina delheidi Vincent in the Nummulite Eocene of the Tatra Mts. Acta Geologica Polonica, 23, 491-497.

Bitner, M. A. 1996. Brachiopods from the Eocene La Meseta Formation of Seymour Island, Antarctic Peninsula. In: Palaeontological Results of the Polish Antarctic Expeditions. Part II (Ed. A. Gazdzicki). Palaeontologia Polonica, 55, 65-100.

Calzada, S. 1994. Revisión de Terebratula sampelayoi, braquiópodo del Eoceno catalán. Batalleria, 4, 41-44.

Calzada, S. y Urquiola, M. M. 1994. Sobre las Argyrotheca (Brachiopoda) del Eoceno surpirenaico. Batalleria, 4, $17-25$.

Calzada, S., Seguier, J. et Tambareau, Y. 1988. Leymerithyris n. gen. montolearensis (Leymerie, 1846), brachiopode de l'Ilerdien circum-pyrénéen. Implications chronostratigraphiques et paléoécologiques. Bulletin de la Société d'Études Scientifiques de l'Aude, 88, 37-44.

Cooper, G. A. 1979. Tertiary and Cretaceous brachiopods from Cuba and the Caribbean. Smithsonian Contributions to Paleobiology, 37, 1-45.

Cooper, G. A. 1988. Some Tertiary brachiopods of the East Coast of the United States. Smithsonian Contributions to Paleobiology, 64, 1-45.

Cossmann, M. 1902. Catalogue illustré des coquilles fossiles de l'Éocène des environs de Paris. Annales de la Société Royale Malacologique de Belgique, 36, 9-100.

Cossmann, M. et Pissarro, G. 1903. Faune éocénique du Cotentin (Mollusques). Tome II. Bulletin de la Société Géologique de Normandie, 22, 5-122.
Curry, G. B. 1981. Variable pedicle morphology in a population of the Recent brachiopod Terebratulina septentrionalis. Lethaia, 14, 9-20.

Dainelli, G. 1915. L'Eocene friulano. Monografia geologica e paleontologica. Memorie Geografiche, Firnze, 721 pp.

Davidson, T. 1852. Monograph of the British Fossil Brachiopoda. Palaeontographical Society, Monograph, 1, 1-117.

Davidson, T. 1870. On Italian Tertiary Brachiopoda. Geological Magazine, 7, 359-370, 399-408, 460-466.

Davidson, T. 1874. On the Tertiary Brachiopoda of Belgium. Geological Magazine, 1, 150-159.

Doncieux, L. 1905. Catalogue descriptif des fossiles nummulitiques de l'Aude et de l'Hérault. Première partie. Montagne Noire et Minervois. Annales de l'Université de Lyon, nouv. sér. I, 17, 184 pp. Lyon-Paris.

Doncieux, L. 1926. Catalogue descriptif des fossiles nummulitiques de l'Aude et de l'Hérault. Deuxième partie (Fascicule III). Corbières septentrionales. Annales de l'Université de Lyon, nouv. sér. I, 45, 80 pp. LyonParis.

Donovan, S. K., Harper, D. A. T. and Doyle, E. N. 1993. A new smooth-shelled Argyrotheca Dall (Brachiopoda, Articulata) from the Eocene of Jamaica. Journal of Paleontology, 67, 1079-1083.

Elliott, G. F. 1938. A London Clay Brachiopod. Proceeding of the Geologists Association, 49, 128-134.

Elliott, G. F. 1954. New Brachiopoda from the Eocene of England, France and Africa. The Annals and Magazine of Natural History, 12th series, 7, 721-728.

Elliott, G. F. 1955. Additions to the British Eocene brachiopod fauna. Geological Magazine, 42, 168-172.

Endo, K., Curry, G. B., Quinn, R., Collins, M. J., Muyzer, G. and Westbroek, P. 1994. Re-interpretation of terebratulide phylogeny based on immunological data. Palaeontology, 37, 349-373.

Fabiani, R. 1913. I Brachiopodi terziari del Veneto. Memorie dell'Istituto Geologico della R. Universitá di Padova, 2, 3-42.

Gochev, P. 1933. Paläontologische und stratigraphische Untersuchungen über das Eocän von Varna. Zeitschrift der Bulgarischen Geologischen Gesellschaft, 5, 1-82. [In Bulgarian with German abstract].

Hatai, K. M. 1940. The Cenozoic Brachiopoda from Japan. The Science Reports of the Tohoku Imperial University, Sendai, Japan, Second Series (Geology), 20, 1-413.

Lee, D. E. 1986. Paleoecology and biogeography of the New Zealand Paleogene brachiopod fauna. In: Les Brachiopodes fossiles et actuels (Eds. P. R. Racheboeuf and C. C. Emig). Biostratigraphie du Paléozö̈que, 4, 477-483.

Leymerie, M. A. 1846. Mémoire sur le terrain à Nummulites (Epicrétacé) des Corbières et de la Montagne Noire. Mémoires de la Société Géologique de France, deuxième série, T. I, no. 8, 337-373.

Linnaeus, C. 1758. Systema naturae. L. Salrii, Stockholm, $823 \mathrm{pp}$.

MacKinnon, D. I. and Smirnova, T. N. 1995. Scanning electron microscopy study of Cretaceous brachiopods of the new family Praeargyrothecidae: implications for 
megathyroid systematics and terebratulide phylogeny. Journal of Paleontology, 69, 670-685.

Makarenko, D. E. 1974. A new species of Crania from the Upper Eocene of the Ukraine. Paleontologicheskiy Sbornik, 11, 46-49. [In Russian].

Mallada, L. 1878. Descripción física y geológica de la provincia de Huesca. Memorias de la Comisión del Mapa Geológico de España, 439 pp.

Mantell, G. 1822. The fossils of the South Downs; or illustrations of the Geology of Sussex. Lupton Relfe, London, $327 \mathrm{pp}$.

Meznerics, I. 1943. Die Brachiopoden des ungarischen Tertiärs. Annales Historico-Naturales Musei Nationalis Hungarici, 36, 10-60.

Molina, E. 1996. El límite Paleoceno/Eoceno en España: características y posibilidades. Geogaceta, 20, 16681671.

Molina, E., Canudo, J. I., Guernet, C., McDougall, K., Ortiz, N., Pascual, J. O., Parés, J. M., Samsó, J. M., Serra-Kiel, J. and Tosquella, J. 1992. The stratotypic Ilerdian revisited: integrated stratigraphy across the Paleocene/Eocene boundary. Revue de Micropaléontologie, 35, 143-156.

Morgan, J. de 1883. Note sur quelques espèces nouvelles de Mégathyridés. Bulletin de la Société Zoologique de France, 8, 371-396.

Nyst, P.-H. 1843. Description des coquilles et des polypiers fossiles des terrains tertiaires de la Belgique. M. Hayez, Bruxelles, pp. 3-675.

Oppenheim, P. 1896. Die Eocaenfauna des Monte Postale bei Bolca im Veronesischen. Palaeontographica, 43, 125-222.

Oppenheim, P. 1901a. Die Priabonaschichten und ihre Fauna im Zusammenhange mit gleichalterigen und analogen Ablagerungen. Palaeontographica, 47, 1-348.

Oppenheim, P. 1901b. Über einige alttertiäre Faunen der Österreichisch-Ungarischen Monarchie. Beiträge zur Paläontologie und Geologie Osterreich-Ungarns und des Orients, 13, 145-277.

Oppenheim, P. 1903. Ueber die Ueberkippung von S. Orso, das Tertiär des Tretto und Fauna wie Stellung der Schioschichten. Zeitschrift der Deutschen geologischen Gesellschaft, 55, 98-235.

Owen, E. F. 1988. Cenomanian brachiopods from the Lower Chalk of Britain and northern Europe. Bulletin of the British Museum (Natural History), Geology series, 44, 65-175.

Pajaud, D. et Plaziat, J.-C. 1972. Brachiopodes thanétiens du synclinal sud-cantabrique au S.-E. de Victoria (Pays Basque espagnol). Étude systématique et interprétation paléoécologique. Bulletin de la Société d'Histoire Naturelle de Toulouse, 108, 446-473.

Pajaud, D. et Tambareau, Y. 1970. Brachiopodes nouveaux du "Sparnacien" des Petites Pyrénées et du Plantaurel. Bulletin de la Société d'Histoire Naturelle de Toulouse, 106, 312-327.

Popiel-Barczyk, E. 1996. Typ Brachiopoda. In: Budowa geologiczna Polski (Eds. L. Malinowska i M. Piwocki). III. Atlas skamienialości przewodnich i charakterystycznych, 3a, 1, kenozoik, trzeciorzed, 239-246.

Popiel-Barczyk, E. and Barczyk, W. 1987. Eocene brachiopods from Wola Luzanska and Skalnik in the Central Carpathians. Acta Geologica Polonica, 37, 93104.

Risso, A. 1826. Histoire naturelle des principales productions de l'Europe méridionale et particulièrement de celles des environs de Nice et des Alpes maritimes. F.G. Levrault, Paris, 439 pp.

Sacco, F. 1902. I Brachiopodi dei terreni terziarii del Piemonte e della Liguria. Carlo Clausen, Torino, 50 pp.

Sandy, M. R., Squires, R. L. and Demetrion, R. 1995. Middle Eocene terebratulide brachiopods from the Bateque Formation, Baja California Sur, Mexico. Journal of Paleontology, 69, 45-51.

Serra-Kiel, J., Canudo, J. I., Dinarès, J., Molina, E., Ortiz, N., Pascual, J. O., Samsó, J. M. y Tosquella, J. 1993. Cronoestratigrafía de los sedimentos marinos del Terciario inferior de la Cuenca de Graus-Tremp (Zona Central Surpirenaica). Revista de la Sociedad Geológica de España, 7, 273-297.

Sowerby, J. de C. 1826-1829. The Mineral Conchology of Great Britain; or coloured figures and descriptions of those remains of testaceous animals or shells, which have been preserved at various times and depths in the earth. Vol. 6, 1-236. London.

Surlyk, F. 1972. Morphological adaptations and population structures of the Danish chalk brachiopods (Maastrichtian, Upper Cretaceous). Det Kongelige Danske Videnskabernes Selskab, Biologiske Skrifter, 19, $1-57$.

Tosquella, J. 1988. Estudi sedimentològic i biostratigràphic de la Formació Gresos de Roda (Eocè, conca de TrempGraus). Unpublished MS Thesis, Universitat de Barcelona, 1-540 p. Barcelona.

Toulmin, L. D. 1940. Eocene brachiopods from the Salt Mountain limestone of Alabama. Journal of Paleontology, 14, 227-233.

Vincent, E. 1893. Contribution à la paléontologie des terrains tertiaires de la Belgique. Brachiopodes. Annales de la Société Royale Malacologique de Belgique, 28, 3864.

Vincent, E. 1923. Quelques remarques sur des Brachiopodes tertiaires de Belgique et description d'une espèce nouvelle d'Argyrotheca. Annales de la Société Royale Malacologique de Belgique, 53, 49-53.

Wahlenberg, G. 1821. Petrificata telluris Suecanae. Nova Acta Regiae Societatis Scientiarum Upsaliensis, 8, 1116.

Woźny, E. 1977. Pelecypods from the Upper Eocene of East Poland. Acta Palaeontologica Polonica, 22, 93-112.

Zelinskaya, V. A. 1962. Brakhiopody iz verkhnego eocena Ukrainy. Paleontologicheskiy Zhurnal, 2, 106-111.

Zelinskaya, V. A. 1975. Brakhiopody paleogena Ukrainy. Naukova Dumka, Kiev, 148 pp. 